University of Nebraska - Lincoln

DigitalCommons@University of Nebraska - Lincoln

1988

\title{
Queen Pheromone Production and Its Physiological Correlates in Fire Ant Queens (Hymenoptera: Formicidae) Treated with Fenoxycarb
}

\author{
Martin S. Obin \\ Department of Zoology, University of Florida, Gainesville, Fla, 32611 \\ B. Michael Glancey \\ Insects Affecting Man and Animals Research Laboratory, CSDA-ARS, Gainesville, Fla, 32604 \\ W. A. Banks \\ Insects Affecting Man and Animals Research Laboratory, CSDA-ARS, Gainesville, Fla, 32604 \\ Robert K. Vander Meer \\ Insects Affecting Man and Animals Research Laboratory, CSDA-ARS, Gainesville, Fla, 32604
}

Follow this and additional works at: https://digitalcommons.unl.edu/entomologyother

Part of the Entomology Commons

Obin, Martin S.; Glancey, B. Michael; Banks, W. A.; and Vander Meer, Robert K., "Queen Pheromone Production and Its Physiological Correlates in Fire Ant Queens (Hymenoptera: Formicidae) Treated with Fenoxycarb" (1988). Entomology Papers from Other Sources. 105.

https://digitalcommons.unl.edu/entomologyother/105

This Article is brought to you for free and open access by the Entomology Collections, Miscellaneous at DigitalCommons@University of Nebraska - Lincoln. It has been accepted for inclusion in Entomology Papers from Other Sources by an authorized administrator of DigitalCommons@University of Nebraska - Lincoln. 


\title{
Queen Pheromone Production and Its Physiological Correlates in Fire Ant Queens (Hymenoptera: Formicidae) Treated with Fenoxycarb ${ }^{1}$
}

\author{
MARTIN S. OBIN, ${ }^{2,3}$ B. MICHAEL GLANCEY, ${ }^{4}$ \\ W. A. BANKS, ${ }^{4}$ AND ROBERT K. VANDER MEER ${ }^{4}$
}

\begin{abstract}
Ann. Entomol. Soc. Am. 81(5): 808-815 (1988)
ABSTRACT Biological assays were used to evaluate the effect of the insect growth regulator fenoxycarb (ethyl (2-p-phenoxyphenoxy) ethyl carbamate) on production of queen-derived dealation inhibitory pheromone and the queen recognition pheromone of Solenopsis invicta Buren. Treated virgin and mated queens weighed less and were less capable of inhibiting dealation by female alates than were nontreated controls. Virgin queens that gained weight during the experimental trials produced more dealation inhibitory pheromone and more queen recognition pheromone than virgin queens that lost weight. Treated virgin queens with fenoxycarb-induced ovary dysfunction inhibited dealation in proportionally fewer alates than treated virgin queens of similar weight that possessed functional ovaries. However, complete ovarian dysfunction in fenoxycarb-treated virgin queens was not associated with reduced quantities of queen recognition pheromone in queen poison sacs. These data support the views that nutritional as well as endocrine factors regulate queen pheromone release and that dissemination of both queen pheromone components is a function of oviposition rate.
\end{abstract}

KEY WORDS Insecta, queen pheromones, S. invicta, fenoxycarb

IN A NUMBER of social Hymenoptera, integrated colony function and regulation of female reproduction are controlled in part by queen pheromones (reviewed in Fletcher \& Ross 1985). Queen pheromones are an important feature of insect eusociality because they mediate reproductive competition among group-living females and may provide kin recognition cues (Hölldobler \& Michener 1980, Carlin \& Hölldobler 1986). Queen pheromones possess an additional allure for the economic entomologist because pheromone-induced disruption of colony homeostasis and reproduction, or incorporation of queen-produced attractant into bait toxicants, may help control certain hymenopteran pests (see also Fletcher 1986).

An essential feature of queen pheromone systems is the interdependence of mechanisms by which queens are recognized by colony members ("queen recognition") and mechanisms that mediate "queen control" of worker and gyne reproduction (Fletcher \& Ross 1985). Both queen recognition and queen control pheromones are produced by queens of the fire ant, Solenopsis invicta Buren. The volatile queen recognition pheromone (Rocca et al. 1983) is derived from the poison sac and released through the sting apparatus

\footnotetext{
${ }^{1}$ This article reports the results of research only. Mention of a proprietary product does not constitute an endorsement or a recommendation for its use by USDA.

${ }^{2}$ Department of Zoology, University of Florida, Gainesville, Fla. 32611 .

${ }^{3}$ Current address: Department of Biology, Brandeis University, Waltham, Mass. 02254.

'Insects Affecting Man and Animals Research Laboratory, LSDA-ARS, Gainesville, Fla. 32604
}

(Vander Meer et al. 1980). It attracts workers (Jouvenaz et al. 1974) and elicits specific queen-tending behaviors (Glancey 1980, Lofgren et al. 1983). S. invicta workers, like workers of other social $\mathrm{Hy}$ menoptera (Fletcher \& Ross 1985), can distinguish their own queen from foreign, conspecific queens (e.g., see Jouvenaz et al. 1974; Fletcher \& Blum $1981 \mathrm{~b}, 1983 \mathrm{a})$. It is not known whether the queen recognition pheromone derived from the poison sac mediates the colony specific queen discrimination reported by Jouvenaz et al. (1974).

Another queen pheromone, a dealation inhibitory primer pheromone, regulates dealation and the potential reproductive activity of female alates within S. invicta colonies (Fletcher \& Blum 1981a,b, 1983b; Willer \& Fletcher 1986). The pheromone has low volatility and derives from the queen's gaster. In the normal colony life cycle, this pheromone inhibits virgin alates from histolyzing their alary muscles (a nutritional source for newly founding queens), shedding their wings (dealation), and laying reproductive (as opposed to trophic) eggs in the natal nest. The pheromone is believed to act by regulating the secretion of juvenile hormone (JH) in virgins (Fletcher \& Blum 1983a). Inhibited alates eventually leave the colony on mating flights, mate, and subsequently attempt to found new colonies. Like mated colony-founding queens, virgins artificially removed from the presence of the queen undergo alary muscle histolysis, dealation, and accelerated oögenesis and can themselves produce significant quantities of both recognition and inhibitory pheromones within $10 \mathrm{~d}$ of disinhibition (Glancey et al. 1981, Fletcher 1986). 
Positive associations of queen pheromone release and reproductive capability have been obtained for a number of social insects (Fletcher \& Ross 1985). In $S$. invicta the magnitude of dealation inhibition is positively correlated with queen fecundity and with correlates of fecundity, including ovarian development, queen weight, and degree of physogastry (Fletcher \& Blum 1983a,b). However, the relationship between fecundity and queen-recognition pheromone has not been determined.

We report here the effect of fenoxycarb, a nonterpenoid compound with juvenile hormone $(\mathrm{JH})$ activity (Masner et al. 1980), on the production of the dealation inhibitory pheromone and the queen recognition pheromone of $S$. invicta. Colonies treated with fenoxycarb exhibit a dramatic increase in the production of sexuals (Banks 1986). Moreover, many of the female sexuals dealate in these treated colonies. Fenoxycarb drastically curtails ovarian function in S. invicta (Glancey \& Banks in press) and in other insects (Masner et al. 1980). It was predicted that a substance that inhibits or reduces ovarian function (and thus fecundity) should reduce production or dissemination, or both, of queen inhibitory pheromone. Furthermore, if colony control by $S$. invicta queens is mediated by an interdependent "recognition/inhibition system" (Fletcher \& Ross 1985), a similar relationship between ovarian function and queen recognition pheromone might be expected.

\section{Materials and Methods}

Dealation Inhibitory Pheromone Production by Inseminated Queens. All queens were obtained from monogyne (single queen) "source" colonies of various ages and sizes (5,000-60,000 workers) reared from the colony-founding stage and maintained on a diet of honey water, hard-boiled egg, and insect pupae (see Banks et al. [1981] for detailed rearing methods). Eight to $10 \mathrm{wk}$ prior to pheromone tests, 10 source colonies, each composed of 40,000-60,000 workers and $20-30 \mathrm{ml}$ of immatures, were fed $0.5 \mathrm{ml}$ soybean oil containing fenoxycarb [(ethyl 2-( $p$-phenoxyphenoxy) ethyl carbamate), Maag Agrochemicals Ro 13-5223, Vero Beach, Fla.] (Banks et al. in press). Four doses of fenoxycarb were tested- $0.125 \mathrm{mg} /$ colony $(n=3)$, $0.250 \mathrm{mg} /$ colony $(n=3), 0.500 \mathrm{mg} /$ colony $(n=$ $3)$, and $1.00 \mathrm{mg} /$ colony $(n=1)$. This dosage range was previously determined to produce both ovarycompetent as well as ovary-incompetent virgin females (see Virgin Queen Test No. 2). Controls received only the regular diet.

The bioassay was modified from one developed by Fletcher \& Blum (1981b). Individual queens were removed from source colonies, weighed ( $\pm 0.004 \mathrm{mg}$ ) on a Mettler balance, and then introduced along with five female alates (stock alates) into a plastic cup $(3.0 \mathrm{~cm}$ high, $3.0 \mathrm{~cm}$ diameter at base) with a damp, Castone floor. Ten control cups, each containing six stock alates and no in- seminated queen, were also established. The stock alate pool represented an approximately $1: 1 \mathrm{mix}$ ture of alates removed at the beginning of behavioral tests from two additional monogyne laboratory colonies containing physogastric queens. Alates had eclosed at least $17 \mathrm{~d}$ before the tests and were therefore considered fully mature (B.M.G., unpublished data). Alates were not weighed. Cups were sealed and covered with aluminum foil for $5 \mathrm{~d}$, when the number of dealated stock alates in each cup was assessed (maximum recorded for control cups was $n-1=5$ ).

Pheromone Production by Virgin Queens: Dealation Inhibitory Bioassay. Female alates were removed from monogyne colonies $(n=3)$ treated (as above) with $0.250 \mathrm{mg} /$ colony fenoxycarb and from two nontreated polygyne (multiple queens) laboratory colonies. Alates from polygyne laboratory colonies tend to be smaller than alates from monogyne colonies. This fact allowed us to match more precisely by weight the treated and untreated virgin queens in Virgin Queen Test No. 2. All alates used in the experiment were at least $17 \mathrm{~d}$ posteclosion. They were established individually in plastic cups for $10 \mathrm{~d}$, during which time dealation occurred. Fully dealated females, hereafter referred to as "virgin queens," were marked by clipping the distal antennal segment, weighed, and placed in a cup containing five stock alates from a third polygyne colony. Cups were capped and covered with aluminum foil for $5 \mathrm{~d}$, when the number of dealated stock alates was assessed. When dealation was not evident, dissection established whether or not wing muscle histolysis had occurred (Toom et al. 1976). We excluded from the analysis any replicate in which we noted mortality or distress of the test queen or of any nondealated, stock alate.

Two trials were conducted. In Virgin Queen Test No. 1, 30 fenoxycarb-treated replicates, 30 nontreated replicates, and 20 controls (6 alates, one marked by antennal clipping) were established. In Virgin Queen Test No. 2, 24 fenoxycarb-treated (12 at $0.125 \mathrm{mg}$ and 12 at $0.250 \mathrm{mg} /$ colony) and 12 nontreated replicates were established. In this second experiment, we selected the nontreated virgin queens that weighed the least to match treated and nontreated replicates more precisely for queen weight.

Quantification of Queen Recognition Pheromone in Poison Sacs of Virgin Queens. At the conclusion of the second inhibitory pheromone bioassay, queens were reweighed, chilled, and dissected in deionized water. Poison sacs were extirpated and crushed in 50 microliters of nanograde hexane in a $0.5-\mathrm{ml}$ vial. Vials were capped, sealed with Parafilm, and stored at $-16^{\circ} \mathrm{C}$ during testing. Samples were checked at least biweekly for solvent loss.

Poison sac extracts were bioassayed for recognition pheromone activity at 0.2 gland equivalents per surrogate queen. Based on previous studies (Lofgren et al. 1983), this dose should provide pher- 
omone activity while permitting replicate tests of each gland. Surrogate queens consisted of extracted and oven-dried rubber septa (Lofgren et al. 1983). Ten microliters of a 0.02 poison sac equivalents per microliter solution and 10 microliters of a hexane plug were applied to each cold septum with a 50microliter syringe. The syringe was cleaned with sequential rinses of methanol, methylene chloride, and hexane between each sample preparation. Septa were stored in the freezer for $1 \mathrm{~h}$ prior to testing to allow absorption of the extract by the septa.

Test colonies $(n=12)$ containing $15,000-25,000$ workers and large amounts of brood were established without queens in Williams cells (Banks et al. 1981) 2 wk prior to testing. Ants were obtained from individual monogyne laboratory colonies that were producing worker brood almost exclusively. Test colonies were placed in fluon-coated plastic trays $(64.0$ by 78.5 by $9.5 \mathrm{~cm})$ and provided with water, honey, and insect diet. Colonies were checked during the course of the experiment for the presence of sexual pupae, which were discarded.

Poison sac extracts were numbered and randomly assigned to three different test colonies. Each extract was tested one time in each of the assigned colonies. Two days were required to test each sample once ( 24 samples evaluated in 12 test colonies). After all extracts had been bioassayed once, test colonies were returned to their parent colony for 48-72 h. They were then removed, checked for the presence of female alates (which were discarded), and returned to their appropriate test tray. After $48 \mathrm{~h}$, test colonies were used for the next replicate series of tests.

The bioassay involved placing the surrogate queen septum $20-25 \mathrm{~cm}$ from the test colony cell and subsequently sprinkling the workers and brood throughout the tray. The cell was closed and returned to its original position. Queen recognition activity was evaluated from five weighted behavioral responses elicited from workers by the surrogate queen (Glancey et al. 1983, 1984). These were initial attraction, clustering about the septum, touching or piling of brood against the septum, formation of a trail from the septum to the cell, and retrieval of the septum back into the cell within $1 \mathrm{~h}$. All tests were conducted between 1100 and 1500 hours (EST).

Screening for Intercastes (Ergatogynes). Social insect larvae exposed to exogenous juvenile hormone or hormone analogues often develop into intercastes (reviewed by de Wilde \& Beetsma 1982). These intercastes typically exhibit distinguishing allometry (Wilson 1971), and in the case of fire ants, distinctive venom chemistry blends as well (Glancey et al. 1980). Therefore, we measured interocular distance, pronotal length, and pronotal width at the widest point of 12 virgins (gynes) from monogyne colonies treated with either $0.250 \mathrm{mg}$ fenoxycarb (two colonies) or $0.125 \mathrm{mg}$ fenoxycarb (two colonies); of 12 major workers from these same four treated colonies; and of 12 virgins from non- treated monogyne colonies $(n=4)$. In addition, poison sacs of these 36 individuals were extirpated, extracted in hexane, and analyzed by capillary gasliquid chromatography (Ross et al. 1987) for the presence and quantity of caste-specific venom alkaloid constituents (Brand et al. 1973, Glancey et al. 1980).

Evaluation of Ovarian Development. Ovaries were dissected in deionized water and fixed in Kahle's fixative. After fixation, they were embedded in paraffin, sectioned at $5 \mu \mathrm{m}$, and stained with Harris' hematoxylin and eosin.

Statistical Analysis. Statistical methods were obtained from Steel \& Torrie (1980). Differences in queen weight and recognition pheromone production were tested for statistical significance by twotailed $t$ tests of sample means with unequal variances. Data from dealation inhibitory pheromone bioassays were tested by contingency $\chi^{2}$ methods. Where three hypotheses were tested with the same data (i.e., multiple comparisons), the comparisonwise attained significance level for rejection of the null hypothesis was designated as 0.02 .

Voucher Specimens. Voucher specimens have been deposited in the Arthropod Collection of the Florida Division of Plant Industry (DPI), Gainesville, Fla.

\section{Results}

\section{Inseminated Queens}

Dealation Inhibitory Bioassay. Weights of fenoxycarb-treated queens were significantly less than weights of nontreated queens (Table la). Dealation occurred in a significantly greater proportion of treated than of nontreated replicates (Table la). Similarly, percent total dealation was significantly higher in the presence of fenoxycarb-treated queens than in the presence of nontreated queens (Table 1a). In addition, the frequency of dealation was significantly greater in the presence of control alates than in the presence of fenoxycarb-treated queens (Table 1a.) A significant, inverse correlation was detected between weights of fenoxycarb-treated queens and the number of alates dealating in their presence (Spearman rank correlation: $r=0.74 ; n=$ $10 ; \mathrm{t}=3.11$, df $=8 ; P<0.02$ ). No similar correlation was obtained for nontreated queens.

\section{Virgin Queens}

Screening for Intercastes. Allometry, measured as the means $( \pm \mathrm{SD})$ of ratios of interocular distance and pronotum width, was almost identical in the two groups of virgin queens (treated virgins, $0.88 \pm$ 0.02 ; range, $0.84-0.93 ; n=12$; nontreated virgins, $0.88 \pm 0.03$; range, $0.81-0.93 ; n=12$ ). In contrast, this ratio among major workers was $1.57 \pm 0.06$ (range, $1.47-1.64, n=12$ ). Similar results were obtained when the ratios of interocular distance and pronotal length were compared among the three groups. Quantitative venom alkaloid analysis 
Table 1. Queen weights and results of dealation inhibitory pheromone bioassays of inseminated and virgin $S$. invicta queens

\begin{tabular}{|c|c|c|c|c|c|c|}
\hline \multirow{2}{*}{ Experiment } & \multirow{2}{*}{$n$} & \multirow{2}{*}{$\begin{array}{c}\text { Mean weight } \\
\text { mg }( \pm S D)\end{array}$} & \multicolumn{2}{|c|}{$\begin{array}{l}\text { Replicates with at } \\
\text { least one dealation }\end{array}$} & \multicolumn{2}{|c|}{ Total dealation } \\
\hline & & & $\%$ & $n$ & $\%$ & $n$ \\
\hline \multicolumn{7}{|c|}{ (a) Inseminated queens ${ }^{a}$} \\
\hline $\begin{array}{l}\text { Treated } \\
\text { Nontreated } \\
\text { Alate controls }\end{array}$ & $\begin{array}{l}10 \\
10 \\
10\end{array}$ & $\begin{array}{c}12.14(1.93) \\
15.59(3.82) \\
-\end{array}$ & $\begin{array}{l}90.0 \\
30.0 \\
90.0\end{array}$ & $\begin{array}{l}10 \\
10 \\
10\end{array}$ & $\begin{array}{r}43.0 \\
8.0 \\
62.0\end{array}$ & $\begin{array}{l}50 \\
50 \\
50\end{array}$ \\
\hline \multicolumn{7}{|c|}{ (b) Virgin queen Test $1^{b}$} \\
\hline $\begin{array}{l}\text { Treated } \\
\text { Nontreated } \\
\text { Alate controls }\end{array}$ & $\begin{array}{l}25 \\
23 \\
19\end{array}$ & $\begin{array}{r}6.49(0.99) \\
10.49(1.23) \\
-\end{array}$ & $\begin{array}{l}68.0 \\
26.1 \\
68.4\end{array}$ & $\begin{array}{l}25 \\
23 \\
19\end{array}$ & $\begin{array}{r}44.0 \\
6.1 \\
40.0\end{array}$ & $\begin{array}{r}125 \\
125 \\
95\end{array}$ \\
\hline
\end{tabular}

Tests of significance: mean weight, treated versus nontreated: $\mathbf{t}^{\prime}=2.55, P<0.01$; proportion of replicates with $\geq 1$ dealation, treated versus nontreated: $\chi^{2}=7.50, \mathrm{df}=1, P<0.004$; proportion total dealation, treated versus nontreated: $\chi^{2}=15.41, \mathrm{df}=1, P<$ 0001 ; proportion total dealation, treated versus alate controls: $\chi^{2}=4.01, \mathrm{df}=1, P<0.05$.

1) Tests of significance: mean weight, treated versus nontreated: $\mathrm{t}^{\prime}=12.35, P<0.001$; proportion of replicates with $\geq 1$ dealation, treated versus nontreated: $\chi^{2}=8.43, \mathrm{df}=1, P<0.005$; proportion total dealation, treated versus nontreated: $\chi^{2}=44.90, \mathrm{df}=1, P<$ 0.001 .

of standardized peak areas revealed that poison sacs of all treated virgin queens contained combinations of the cis and trans C-11:0 alkaloids in quantities representative of true gynes (Brand et al. 1973, Glancey et al. 1980).

Dealation Inhibitory Pheromone: Virgin Queen Test No. 1. Twenty-five treated virgin queens, 23 nontreated virgin queens, and 19 alate control replicates were included in the analysis. Treated virgins weighed almost $40 \%$ less than nontreated virgins (Table $1 \mathrm{~b}$ ). The proportion of replicates in which at least one instance of dealation was observed was significantly greater among treated virgin queens than among nontreated virgin queens (Table lb). Similarly, the total frequency of dealation was significantly greater among alates exposed to treated virgins for $5 \mathrm{~d}$ than among alates housed with nontreated virgins (Table $1 b$ ). Frequency of dealation in the presence of treated virgin queens did not differ significantly from that among control alates (Table 1b).

Queen Weight, Alary Muscle Histolysis, and Ovarian Development: Virgin Queen Test No. 2. Data from 17 treated virgin queens and seven nontreated virgin queens were analyzed (Table $2 a$ ). Weights of fenoxycarb-treated virgin queens (mean $\pm \mathrm{SD}=6.03 \pm 0.74 \mathrm{mg}, n=17$ ) and nontreated virgin queens from polygyne colonies (mean $\pm \mathrm{SD}=5.83 \pm 1.39, n=7$ ) were not significantly different $(t=0.36, P>0.90)$. However, 6 of 11 virgin queens exposed to $0.125 \mathrm{mg}$ fenoxycarb gained, on average, $5.5 \%(\mathrm{SD}=3.2 \%)$ of their original weight (determined at the beginning of the bioassay), whereas five virgin queens lost, on average, $5.6 \%(\mathrm{SD}=2.8 \%$ ) of their original weight. Each of the six virgin queens treated at $0.250 \mathrm{mg}$ lost, on average, $20.5 \%(\mathrm{SD}=10.7 \%)$ of their original weight. Six of the seven control alates lost an average of $8.1 \%(\mathrm{SD}=4.0 \%)$ of their original weight.

Wing muscle histolysis had occurred in all treated virgin queens and in all but one of the non- treated virgin queens. All nontreated virgin queens had developed ovaries. Each ovary was at least 3.0 $\mathrm{mm}$ in diameter, and each ovariole contained one or more vitellogenic eggs, with the typical meroistic (polytrophic) pattern of oögonia, primary oöcytes, and nurse cells (trophocytes) with surrounding follicular epithelium (Hermann \& Blum 1965, Glancey \& Banks in press). In contrast, only 9 of 17 treated virgins had developed ovaries. Virgins were considered to lack functional ovaries if serial sectioning revealed only a small $(<0.5 \mathrm{~mm})$ patch of undifferentiated tissue at the tip of each oviduct.

Dealation Inhibitory Pheromone: Virgin Queen Test No. 2. The frequency of dealation in cups containing treated virgin queens ( 23 of 85 ) did not differ significantly from that in cups containing nontreated virgin queens ( 9 of 35 ) (Table $2 a$ ). A significantly greater proportion of alates dealated in the presence of treated virgin queens without ovaries than in the presence of queens with functional ovaries (Table 2a). Also, more alates dealated in the presence of virgins that lost weight during the 5-d test than dealated in the presence of virgins that gained weight (Table 2b). We found no association of weight loss or weight gain by virgin queens with the presence or absence of functional ovaries.

Queen Recognition Pheromone: Virgin Queen Test No. 2. Workers exhibited "brood touch" behavior and retrieved treated septa into test colony cells in response to poison sac extracts of both treated and nontreated virgin queens. Because these responses are not elicited by septa treated with solvent alone, we conclude that poison sacs of treated and nontreated virgin queens contain queen recognition pheromone. Both mean and median scores (of three replicates per poison sac) were obtained for each extract. We detected no significant association between the presence or absence of functional ovaries and scores generated in the surrogate queen bioassay by an individual's poison sac extract (Table $2 a$ ). In addition, mean recognition 
Table 2. Results of Virgin Queen Test No. 2. Queen weights, dealation inhibition pheromone, and queen recognition pheromone bioassays are presented as a function of (a) queen ovarian development, and (b) queen weight gain or loss during testing

\begin{tabular}{|c|c|c|c|c|c|}
\hline \multirow{2}{*}{ Queen status } & \multirow{2}{*}{$n$} & \multirow{2}{*}{$\begin{array}{l}\text { Mean weight } \\
\mathrm{mg}( \pm \mathrm{SD})\end{array}$} & \multicolumn{2}{|c|}{ Total dealation } & \multirow{2}{*}{$\begin{array}{l}\text { Queen recognition } \\
\text { score mean }( \pm \mathrm{SD})\end{array}$} \\
\hline & & & $\%$ & $n$ & \\
\hline \multicolumn{6}{|l|}{ (a) Ovarian development ${ }^{a}$} \\
\hline \multicolumn{6}{|l|}{ Functional } \\
\hline Treated & 9 & $6.04(0.85)$ & 13.3 & 45 & $\begin{array}{l}2.02(0.48)+ \\
1.94(0.50)++\end{array}$ \\
\hline Nontreated & 7 & $5.83(1.39)$ & 25.7 & 35 & $\begin{array}{l}2.23(0.42)+ \\
2.05(0.49)++\end{array}$ \\
\hline \multicolumn{6}{|l|}{ Dysfunctional } \\
\hline Treated & 8 & $6.01(0.63)$ & 42.5 & 40 & $\begin{array}{l}2.20(0.45)+ \\
2.08(0.46)++\end{array}$ \\
\hline Nontreated & 0 & - & - & - & - \\
\hline \multicolumn{6}{|c|}{$\begin{array}{l}\text { (b) Weight gain or loss during } \\
\text { inhibition pheromone bioassay } b\end{array}$} \\
\hline Treated & 6 & - & 13.3 & 30 & $\begin{array}{l}2.31(0.27)+ \\
2.19(0.14)++\end{array}$ \\
\hline Nontreated & l & - & 20.0 & 5 & $\begin{array}{ll}2.52 & + \\
2.65 & ++\end{array}$ \\
\hline \multicolumn{6}{|l|}{ Lost } \\
\hline Treated & 11 & - & 34.5 & 55 & $\begin{array}{l}1.89(0.39)+ \\
1.80(0.41)++\end{array}$ \\
\hline Nontreated & 6 & - & 26.7 & 30 & $\begin{array}{l}2.28(0.15)+ \\
2.11(0.23)++\end{array}$ \\
\hline
\end{tabular}

+ , queen recognition scores based on average of three replicates; ++ , queen recognition scores based on median of three replicates. Significance tests of queen recognition pheromone data use mean group scores computed from the average score of each replicate.

${ }^{a}$ Tests of significance: queen weight, treated versus nontreated: $t^{\prime}=0.36, P>0.50$; queen weight, functional versus dysfunctional ovaries: $t^{\prime}=0.09, P>0.50$; queen weight, functional ovaries, treated versus nontreated: $t^{\prime}=0.29, P>0.50$; proportion total dealation, treated versus nontreated: $\chi^{2}=0.02, \mathrm{df}=1, P>0.80$; proportion total dealation, functional versus dysfunctional ovaries: $\chi^{2}=7.69$, $\mathrm{df}=1, P<0.004$; Queen recognition score, functional versus dysfunctional ovaries: $t^{\prime}=0.26, P>0.50$; queen recognition score, functional versus dysfunctional ovaries (treated): $t^{\prime}=0.36, P>0.50$; queen recognition score, functional ovaries, treated versus nontreated: $t^{\prime}=1.40, P<0.20$.

${ }^{b}$ Proportion total dealation, gained versus lost weight: $\chi^{2}=3.87, \mathrm{df}=1, P=0.05$; chi-proportion total dealation, gained versus lost weight (treated): $\chi^{2}=4.43, \mathrm{df}=1, P<0.05$; queen recognition score, gained verus lost weight: $t^{\prime}=1.32, P>0.20$; queen recognition score, gained versus lost weight (treated): $t^{\prime}=3.21, P<0.02$.

scores and weights of treated virgin queens were not significantly associated (Spearman rank correlation: $r=0.26 ; n=17 ; \mathrm{t}=1.06 ; \mathrm{df}=15 ; P>$ $0.30)$.

However, mean recognition scores of poison sacs from treated virgins that gained weight during the inhibitory bioassay were significantly higher than scores generated by extracts obtained from virgins that lost weight (Table 2b). Lastly, we detected no significant association between the inhibitory capability of a virgin queen and the mean recognition score generated by that queen's poison sac extract in the recognition pheromone assay (Spearman rank correlation: $r=0.043 ; n=24 ; \mathrm{t}=0.20 ; \mathrm{df}=22$; $P>0.75)$.

\section{Discussion}

Inseminated and virgin queens with fenoxycarbinduced ovarian dysfunction weighed less and disseminated less inhibitory pheromone than nontreated queens (Table la, b). These data support previous conclusions (Fletcher \& Blum 1983b, Willer \& Fletcher 1986) concerning positive correlations among weight, ovary development (fecundity), and inhibitory pheromone production by mated and virgin $S$. invicta queens.
Treated, inseminated queens did possess some inhibitory capability, for these queens inhibited dealation in proportionally more alates than did virgin alate controls (Table la). This finding is consistent with our observation that low doses of fenoxycarb $(<1.0 \mathrm{mg} /$ colony) severely impair but do not necessarily eliminate oögenesis and oviposition in mated, physogastric queens (Glancey \& Banks in press).

Colonies treated with low doses of fenoxycarb often produce ovary-competent as well as ovaryincompetent female sexuals. However, because colonies subjected to IGR treatment often produce an abnormally high proportion of intercastes (Robeau \& Vinson 1976), we felt it necessary to determine whether the treated virgins in our study were, in fact, true gynes. Our morphometric and biochemical data give us no reason to believe they are not. At present we suspect that differential feeding of fenoxycarb interacts with differences in developmental timing ("gates") among larvae to account for the concurrent production of ovary-competent and ovary-incompetent alates in the same colony.

In any case, the treated virgins in our study were underweight gynes rather than intercastes and, as we noted with mated queens, these virgin queens 
also displayed decrements in inhibitory pheromone release (Virgin Queen Test No. 1). The inhibitory capability of treated virgins did not differ significantly from the inhibitory capability of alate controls; this lack of difference suggests that, although disinhibited for $10 \mathrm{~d}$ prior to testing, treated virgins released amounts of inhibitory pheromone as low as those released by fully inhibited alate controls. In Virgin Queen Test No. 2 we evaluated pheromone production among sibling virgin queens of similar weight from treated colonies. Some of these virgins possessed functional ovaries and some lacked them. Results (Table 2a) indicate that when fenoxycarb prevents ovarian development, it also significantly impairs inhibitory pheromone release. An accurate measure of the extent of these reductions in queen pheromone production among treated virgins requires the use of nontreated virgins from monogyne colonies. The nontreated, virgin queens used in this study were from polygyne (multiple-queen) colonies, and quantitative comparison of pheromone production by the two types of virgin queens remains to be conducted (see discussion in Willer \& Fletcher 1986).

Although ovarian development is positively associated with the release of inhibitory pheromone, we detected no association between presence or absence of functional ovaries and the quantity of queen recognition pheromone in the poison sacs of virgin queens. We also failed to detect any significant correlation between the inhibitory capability of virgin queens and the quantity of recognition pheromone in their poison sacs. Nevertheless, we suggest that the two pheromone systems work in concert, and that dissemination of both queen pheromones is fecundity-dependent. Our reasoning is as follows: Knowing that, during oviposition, queens apply poison sac materials (i.e., venom) to the eggs (Vander Meer 1983), we feel it highly probable that queen recognition pheromone is also released during oviposition. Because oviposition rate is a function of fecundity (Fletcher \& Blum 1983a), quantitative release of recognition pheromone is likely to reflect fecundity. Furthermore, as the inhibitory pheromone is relatively nonvolatile Fletcher \& Blum 1981b), its efficacy may depend on contact or close association of queens with colony members and subsequent dissemination of the inhibitory substance(s) to target alates by workers (Vander Meer 1983, Fletcher 1986). It is quite likely that the frequency and,duration of queen-worker contact is positively correlated with oviposition rate insofar as this rate determines the quantitative release of the queen recognition attractant.

We were intrigued by the positive association between weight gain by virgin queens and the release of both inhibitory and recognition-attractant pheromones. It is known that virgin dealates, called "virgin replacement queens," are sometimes found in queenright colonies, and that these virgin dealates vary widely in their degree of physogastry (Tschinkel \& Howard 1978). Fletcher \& Blum (1983a) suggest that virgin dealates receive differential amounts of a nutritional factor. We hypothesize that the observed weight gain by particular virgin queens during the inhibitory pheromone bioassay reflected feeding (trophallaxis) by alates with whom they were housed. (Queens that lost weight may have also received food.) If differential feeding of reproductives does occur, it is unclear whether it is mediated by quantitative differences in queen pheromone release by virgins or whether pheromonal differences are a consequence of differential feeding. Clearly the possibility exists for positive feedback between nutritional state and pheromone production by queens.

In addition to the role of queen nutritional state, Fletcher \& Blum (1983a) suggest that inhibitory pheromone production reflects queen hormonal state and, in particular, levels of JH. Fenoxycarb not only inhibits ovarian development in gynes, but it also shifts colony caste production from workers to sexual forms (Banks 1986). These effects are identical with those obtained with $\mathrm{JH}$ or $\mathrm{JH}$ analogues in a variety of social insects (de Wilde \& Beetsma 1982), including $S$. invicta (reviewed by Passera 1982). It is believed that the IGR activity of fenoxycarb is enhanced as a consequence of its resistance to enzymatic breakdown in vivo, and because it inhibits hydrolytic decomposition of endogenous $\mathrm{JH}$, thereby acting as a synergist (Masner et al. 1980).

Barker (1978, 1979) observed that allatectomy disrupted normal alary muscle histolysis and dealation in S. invicta virgin queens, and that exogenous $\mathrm{JH}$ could restore these functions. In addition, he reported that topical $\mathrm{JH}$ treatments increased oviposition rates in these virgins. Based on these data and on studies with other social $\mathrm{Hy}$ menoptera (reviewed in de Wilde \& Beetsma 1982), Fletcher \& Blum (1983a) suggested that the dealation inhibitory pheromone acts on the corpora allata (CA) of S. invicta gynes to reduce the secretion of $\mathrm{JH}$. The reduced $\mathrm{JH}$ titer is believed to promote a low rate of sexual maturation, oögenesis, and vitellogenesis, whereas a substantially higher titer (resulting from disinhibition) is necessary for alary muscle histolysis. However, we noted that all $(n=17)$ fenoxycarb-treated virgin queens in our study underwent alary muscle histolysis, yet eight of these lacked ovaries. Resolution of this apparent contradiction requires more precise knowledge of $\mathrm{JH}$ or $\mathrm{JH}$ analogue titers in individual gated insects.

Do JH levels control queen pheromone production by $S$. invicta? Evidence for endocrine or neuroendocrine control of pheromone production has been demonstrated for cockroaches (Barth 1965, Bell \& Barth 1970), beetles (Borden et al. 1969, Harring 1978), and moths (Raina \& Klun 1984). The fact that queens exposed to fenoxycarb in our study produced less dealation inhibitory pheromone than nontreated controls suggests the possibility of a mechanism of control involving $\mathrm{JH}$. With respect to the queen recognition pheromone, we 
propose that $\mathrm{JH}$ titers affect pheromone release to the extent that these titers mediate fecundity and consequent rates of oviposition. The interaction of queen pheromones with gyne nutritional and endocrinological states promises to be an exciting area of future study.

\section{Acknowledgment}

We thank Terry Krueger and Dorman Hicks for assistance in the laboratory, and Stuart Krasnof, Lloyd Davis and two anonymous reviewers for suggestions that improved the manuscript. This research was supported by the Agricultural Research Service, U.S. Department of Agriculture.

\section{References Cited}

Banks, W. A. 1986. Insect growth regulators for control of the imported fire ant, pp. 387-398. In C. S. Lofgren \& R. K. Vander Meer [eds.], Fire ants and leaf-cutting ants: biology and management. Westview, Boulder, Colorado.

Banks, W. A., C. S. Lofgren, D. P. Jouvenaz, C. E. Stringer, P. M. Bishop, D. F. Williams, D. P. Woj cik \& B. M. Glancey. 1981. Techniques for collecting, rearing and handling imported fire ants. USDA, Science and Education Administration AATS-S-21.

Banks, W. A., D. F. Williams \& C. S. Lofgren. In press. Effectiveness of fenoxycarb for control of red imported fire ants. J. Econ. Entomol.

Barker, J. F. 1978. Neuroendocrine regulation of oöcyte maturation in the imported fire ant Solenopsis invicta. Gen. Comp. Endocrinol. 35: 234-237.

1979. Endocrine basis of wing casting and flight muscle histolysis in the fire ant Solenopsis invicta. Experientia 35: 552-554

Barth, R. H. 1965. Insect mating behavior: endocrine control of a chemical communication system. Science 149: 882-883.

Bell, W. J. \& R. H. Barth. 1970. Quantitative effects of juvenile hormone on reproduction in the cockroach Byrsotria fumigata. J. Insect Physiol. 16: 2303-2313.

Borden, J. H., K. K. Nair \& C. E. Slater. 1969. Synthetic juvenile hormone: induction of sex pheromone production in Ips confusus. Science 166: 1626-1627.

Brand, J. M., M. S. Blum \& M. R. Barlin. 1973. Fire ant venoms: intraspecific and interspecific variation among castes and individuals. Toxicon 11: 325-331.

Carlin, N. F. \& B. Hölldobler. 1986. The kin recognition system of carpenter ants (Camponotus spp.). Behav. Ecol. Sociobiol. 19: 123-134.

Fletcher, D. J. C. 1986. Perspectives on some queen pheromones of social insects with special reference to the fire ant, Solenopsis invicta, pp. 184-191. In C. S. Lofgren \& R. K. Vander Meer [eds.], Fire ants and leaf-cutting ants: biology and management. Westview, Boulder, Colo.

Fletcher, D. J. C. \& M. S. Blum. 1981a. Pheromonal control of dealation and oögenesis in virgin queen fire ants. Science 212: 73-75.

1981b. A bioassay technique for an inhibitory pheromone of the fire ant, Solenopsis invicta Buren. J. Ga. Entomol. Soc. 16: 352-356.

1983a. The inhibitory pheromone of queen fire ants: effects of disinhibition on dealation and oviposition by virgin queens. J. Comp. Physiol. 153: 467-475. 1983b. Regulation of queen number by workers in colonies of social insects. Science 219: 312-314.

Fletcher, D. J. C. \& K. G. Ross. 1985. Regulation of reproduction in eusocial Hymenoptera. Annu. Rev. Entomol. 30: 319-343.

Glancey, B. M. 1980. Biological studies on the queen pheromone of the red imported fire ant, pp. 149159. In Ecological animal control by habitat management. The fire ant problem. No. 7, Tall Timbers Research Station, Tallahassee, Fla.

Glancey, B. M. \& W. A. Banks. In press. Effect of the insect growth regulator fenoxycarb on the ovaries of queens of the red imported fire ant (Hymenoptera: Formicidae). Ann. Entomol. Soc. Am.

Glancey, B. M., R. K. Vander Meer, A. Glover \& C. S. Lofgren. 1980. Observations of intercastes in Solenopsis invicta Buren (Note). Fla. Entomol. 63: 346350.

Glancey, B. M., A. Glover \& C. S. Lofgren. 1981. Pheromone production by virgin queens of Solenopsis invicta Buren. Sociobiology 6: 119-127.

Glancey, B. M., J. Rocca, C. S. Lofgren \& J. Tumlinson. 1983. Behavior of disrupted colonies of Solenopsis invicta towards queens and pheromone-treated surrogate queens placed outside the nest. Sociobiology 7: 283-288.

1984. Field tests with synthetic components of the queen recognition pheromone of the red imported fire ant, Solenopsis invicta Buren. Sociobiology 9: 1930.

Harring, C. M. 1978. Aggregation pheromones of the European fir engraver beetles Pityokteines curvidens, $P$. spinidens and $P$. vorontzovi and the role of juvenile hormone in pheromone biosynthesis. Z. Angew. Entomol. 85: 281-317.

Hermann, H. R., Jr., \& M. S. Blum. 1965. Morphology and histology of the reproductive system of the imported fire ant queen, Solenopsis saevissima richteri. Ann. Entomol. Soc. Am. 58: 81-89.

Hölldobler, B. \& C. D. Michener. 1980. Mechanisms of identification and discrimination in social Hymenoptera, pp. 35-58. In H. Markl [ed.], Evolution of social behavior: hypotheses and empirical tests. Dahlem Konferenzen 1980. Verlag Chemie, Weinheim, German Federal Republic.

Jouvenaz, D. P., W. A. Banks \& C. S. Lofgren. 1974. Fire ants: attraction of workers to queen secretions. Ann. Entomol. Soc. Am. 67: 442-444.

Lofgren, C. S., B. M. Glancey, A. Glover, J. Rocea \& J. Tumlinson. 1983. Behavior of workers of Solenopsis invicta (Hymenoptera: Formicidae) to the queen recognition pheromone: laboratory studies with an olfactometer and surrogate queens. Ann. Entomol. Soc. Am. 76: 44-50.

Masner, P., S. Dorn, w. Vogel, M. Kalin, O. Graf \& E. Gunthart. 1980. Types of response of insects to a new IGR and to proven standards. Scientific Papers of Institute of Organic and Physical Chemistry, Wroclaw Technical University, Poland, No. 22, Conference 7, pp. 809-818.

Passera, L. 1982. Endocrine regulation of caste determination in ants, pp. 41-61. In P. Jaisson [ed.], Social insects in the tropics, vol. 1. Presses de l'Université de Paris XIII, Paris.

Raina, A. K. \& J. A. Klun. 1984. Brain factor control of sex pheromone production in the female corn earworm moth. Science 225: 531-532.

Robeau, R. M. \& S. B. Vinson. 1976. Effects of ju- 
venile hormone analogues on caste differentiation of the imported fire ant, Solenopsis invicta. J. Ga. Entomol. Soc. 11: 198-203.

Rocea, J. R., J. H. Tumlinson, B. M. Glancey \& C. S. Lofgren. 1983. The queen recognition pheromone of Solenopsis invicta: preparation of (E)-6-(1-pentenyl)-2-H-pyran-2-one. Tetrahedron Lett. 24: 1889 1892.

Ross, K. G., R. K. Vander Meer, D. J. C. Fletcher \& E. L. Vargo. 1987. Biochemical, phenotypic and genetic studies of two introduced fire ants and their hybrid (Hymenoptera: Formicidae). Evolution 41: 280-293.

Steel, R. G. D. \& J. H. Torrie. 1980. Principles and procedures of statistics with special reference to the biological sciences. McGraw-Hill, New York.

Toom, P. M., C. P. Johnson \& E. W. Cupp. 1976. Utilization of body reserves during preoviposition activity by Solenopsis invicta. Ann. Entomol. Soc. Am. 69: 145-148.

Tschinkel, W. R. \& D. F. Howard. 1978. Queen replacement in orphaned colonies of the fire ant, Solenopsis invicta. Behav. Ecol. Sociobiol. 12: 103-113.

Vander Meer, R. K. 1983. Semiochemicals of the red imported fire ant (Solenopsis invicta Buren) ( $\mathrm{Hy}-$ menoptera: Formicidae). Fla. Entomol. 66: 139-161.

Vander Meer, R. K., B. M. Glancey, C. S. Lofgren, A Glover, J. H. Tumlinson \& J. Rocea. 1980. The poison sac of red imported fire ant queens: source of a pheromone attractant. Ann. Entomol. Soc. Am. 73: 609-612.

Wilde, J. de \& J. Beetsma. 1982. The physiology of caste development in social insects. Adv. Insect Physiol. 16: 167-246.

Willer, D. E. \& D. J. C. Fletcher. 1986. Differences in inhibitory capability among queens of the ant Solenopsis invicta. Physiol. Entomol. 11: 475-482.

Wilson, E. O. 1971. The insect societies. Belknap, Cambridge, Mass.

Received for publication 27 April 1987; accepted 23 February 1988. 